\title{
PENGARUH KECERDASAN EMOSIONAL DAN STRES KERJA TERHADAP KINERJA KARYAWAN PADA PT LAJU PERDANA INDAH DI OKU TIMUR
}

\author{
Dita Marisa Putri ${ }^{1)}$, Syaiful Sahri ${ }^{2)}$ \\ 1. Dosen Program Studi Administrasi Negara, STIA Satya Negara, Sumatera Selatan \\ ${ }^{1)}$ Email: ditamarisa87@gmail.com \\ 2'Dosen jurusan Manajemen, Universitas Tridinanti, Sumatera Selatan \\ ${ }^{2)}$ Email: syaifulsahri11@gmail.com
}

\begin{tabular}{l} 
INFORMASI ARTIKEL \\
\hline Submitted: \\
$01 / 11 / 2021$ \\
Revised: \\
15/12/2021 \\
Accepted: \\
25/12/2021 \\
Online-Published: \\
31/12/2021
\end{tabular}

\begin{abstract}
ABSTRAK
Tujuan dari penelitian ini adalah (1) Untuk mengetahui pengaruh kecerdasan emosional dan stres kerja secara bersama - sama terhadap kinerja karyawan pada PT Laju Perdana Indah di Oku Timur. (2) Untuk mengetahui pengaruh kecerdasan emosional terhadap kinerja karyawan pada PT Laju Perdana Indah di Oku Timur. (3) Untuk mengetahui stres kerjaterhadap kinerja karyawan pada PT Laju Perdana Indah di Oku Timur.

Hasil penelitian menunjukkan Secara simultan atau bersama - sama ada pengaruh Kecerdasan Emosional $\left(\mathrm{X}_{1}\right)$ dan Stres kerja $\left(\mathrm{X}_{2}\right)$ terhadap Kinerja Kerja Karyawan(Y) hal ini dapat dilihat dari hasil uji F (ANOVA) Apabila dilihat dari nilai Signifikannya $0,000 \leq(\alpha) 0,05$. Dari hasil analisis Uji Koefisien Korelasi sederhana, nilai korelasi antara variabel Kecerdasan Emosional dengan variabel Kinerja kerja karyawan sebesar 0,811 angka tersebut menunjukkan bahwa terdapat korelasi yang kuat antara variabel Kecerdasan Emosional dengan variabel Kinerja kerja karyawan. Begitu juga nilai korelasi antara variabel Stres kerja dengan variabel Kinerja kerja karyawan adalah sebesar 0,811 angka tersebut juga menunjukkan bahwa terdapat korelasi yang kuat antara variabel Stres kerja dengan variabel Kinerja kerja karyawan.

Kata Kunci : Kecerdasan Emosional, Stres Kerja
\end{abstract}

\begin{abstract}
Effect of Emotional Intelligence and Job Stress on Employee Performance at PT Laju Perdana Indah in East Oku. The aims of this study are (1) to determine the effect of emotional intelligence and work stress together on employee performance at PT Laju Perdana Indah in East Oku. (2) To determine the effect of emotional intelligence on employee performance at PT Laju Perdana Indah in East Oku. (3) To determine work stress on employee performance at PT Laju Perdana Indah in East Oku. The results of the study show that simultaneously or together there is an influence of Emotional Intelligence (X1) and work stress (X2) on Employee Work Performance (Y) this can be seen from the results of the F test (ANOVA). 0.05. From the results of the simple Correlation Coefficient Test analysis, the correlation value between the Emotional Intelligence variable and the employee work performance variable is 0.811 , this number indicates that there is a strong correlation between the Emotional Intelligence variable and the employee work performance variable. Likewise, the correlation value between the work stress variable and the employee work performance variable is 0.811 . This number also shows that there is a strong correlation between the work stress variable and the employee work performance variable.

Keywords: Emotional Intelligence, Job Stress
\end{abstract}

\section{A. PENDAHULUAN}

Sumber daya manusia merupakan aset paling penting dalam suatu organisasi karena merupakan sumber daya yang mengarahkan organisasi serta mempertahankan dan mengembangkan organisasi dalam berbagai tuntutan masyarakat dan zaman oleh karna itu sumber daya manusia harus diperhatikan, dijaga dan dikembangkan. Proses untuk menghasilkan sumber daya manusia harus didukung dengan 
kecerdasan emosional yang tinggi dari pegawai agar dapat menguasai dan bertanggung jawab dalam menjalankan tugas dengan baik. Kecerdasan emosional menuntut pemilik perasaan untuk belajar jujur,menghargai perasaan diri sendiri dan orang lain,menanggapinya dengan tepat serta menerapkan secara efektif energi emosi dalam kehidupan sehari-hari.

Kecerdasan emosinal yang ada pada diri seseorang adalah mencakup pengendalian diri, semangat, ketekunan, serta kemampuan untuk memotivasi diri sendiri. Bila seseorang dapat memotivasi diri sendiri memungkinkan kinerja yang tinggi dalam segala bidang pekerjaan. Kecerdasan emosi adalah kecakapan hasil belajar yang menghasilkan hasil kinerja yang menonjol. Inti kecakapan ini adalah dua kemampuan yaitu empati, adalah dapat memahami perasaan orang lain dan ketrampilan social adalah mampu mengelola perasaan orang lain dengan baik. (Goleman, 2001)

Penelitian terdahulu jorfi (2010) yang berjudul impact of emosional intelligence on perfomance bahwa dari hasil tersebut diketahui bahwa terdapat pengaruh positif antara kecerdasan emosional terhadap tingkat kinerja di level manajer dan pegawai administrasi di iran. Kecerdasan emosional sangat diperlukan oleh karyawan agar dapat mengatasi stres, Kecerdasan emosional dapat mengatasi masalah karena dapat mengatur emosi diri sendiri sehingga mudah menyelesaikan masalah.Kecerdasan emosional sangat berpengaruh dalam dunia kerja karena kecerdasan emosional memungkinkan karyawan untuk mengelola emosinya dengan baik sehingga membawa karyawan tersebut bekerja secara tepat dan efektif untuk mencapai sasaran dan tujuan perusahaan, hal ini dinyatakan pada penelitian Rahim (2010); Darvish (2011); Çekmecelioglu (2012); dan Karambut (2012).Menurut Carmichael dalam Supriyanto dkk. (2012), kecerdasan emosional merupakan proses spesifik dari kecerdasan informasi yang meliputi kemampuan dalam mengekspresikan emosi diri sendiri kepada orang lain, pengaturan emosi untuk mencapai tujuan.Kecerdasan emosional yang tinggi akan membantu karyawan dalam mengatasi konflik secara tepat dan menciptakan kondisi kerja yang baik sedangkan kecerdasan emosional yang rendah akan berdampak buruk karena karyawan kurang dapat pengambilan keputusan dan tidak bisa menghadapi konflik secara tepat.

Selain itu Salah satu hal yang dapat memberikan pengaruh pada kinerja karyawan adalah Stres kerja, stres kerja dapat membuat seorang karyawan menduakan pekerjaanya. Stres yang dialami seseorang bisa dari dalam perusahaan atau luar perusahaan. Masalah stres kerja didalam organisasi menjadi gejala yang penting diamati sejak mulai timbulnya tuntutan untuk efisien didalam pekerjaan. Setiap tenaga kerja bekerja sesuai dengan perananya dalam organisasi, artinya setiap tenaga kerja mempunyai kelompok tugasnya yang harus dilakukan sesuai dengan aturanaturan yang ada dan sesuai dengan yang diharapkan oleh atasanya. Namun dengan demikian tenaga kerja tidak selalu berhasil untuk memainkan perananya tanpamenimbulkan masalah. Kurang baik berfungsinya peran, yang merupakan pembangkit stres yaitu meliputi konflik peran dan ketaksaan peran (role ambiguity) (Hidayanti, 2008). Hal yang sama dinyatakan oleh Rosidah (2013) dalam temuanya yang menunjukan ada korelasi negatif antara stres kerja dengan kinerja pada karyawan, yang berarti semakin tinggi stres kerja maka akan semakin rendah kinerja karyawan.

Stres biasanya dianggap sesuatu yang buruk , stres dianggap terjadi karena disebabkan oleh faktor negatif, stres kerja merupakan suatu bentuk interaksi individu terhadap lingkungannya. Stres sebenarnya dapat dilihat dari dua sisi yaitu sisi positif dan sisi negatif. Stress yang dikondisikan sebagai sesuatu yang negatif disebut distres, sedangkan stres yang memberikan dampak positif disebut eustress. Stress yang sering kita alami dalam kehidupan kerja dan kehidupan pribadi bukanlah hal yang baru, sebagian besar dari kita menyadari bahwa stress merupakan masalah yang semakin banyak dijumpai dalam organisasi (robbins dan Judge, 2008). Stres kerja merupakan salah satu faktor internal karyawan atau pegawai yang menghasilan perilaku kerja yang nantinya berpengaruh dalam menentukan kinerja (wirawan, 2009). Usaha 
dalam meningkatkan kapasitas kerja yang nyaman sehingga dapat meningkatkan gairah atau semangat kerja pegawai.

Perusahaan menginginkan karyawan yang memiliki integritas tinggi dalam melakukan pekerjaan.Stres diakibatkan oleh tuntutan profesionalitas karyawan seperti beban kerja yang semakin berat, adanya persaingan yang semakin ketat dan tingkat pendapatan yang tidak seimbang dengan biaya hidup. Menurut Handoko(2008), stres kerja yaitu suatu kondisi emosi dimana dipengaruhi oleh ketegangan, proses berpikir seseorang. Stres kerja yaitu kondisi perasaan tertekan para karyawan dalam menjalankan pekerjaan (Mangkunegara, 2009).

Menurut Suwarto (2014) kinerja didefinisikan sebagai perilaku atau apa yang dilakukan karyawan, bukannya apa yang diproduksi atau apa yang dihasilkan dari kerja mereka.Ini berarti bahwa terdapat banyak jenis perilaku berbeda-beda yang mempunyai kapasitas untuk memajukan (atau menghambat) tujuan organisasi. Dengan demikian, maka definisi kinerja tidak mencakup hasil dari perilaku pegawai, tetapi perilaku itu sendiri (Suwarto, 2014).

Peningkatan kinerja karyawan secara perorangan akan mendorong kinerja sumber daya manusia secara keseluruhan, yang dikaitkan dalam kenaikan produktivitas kinerja karyawan. penilaian kinerja karyawan merupakan suatu hal yang tidak dapat dipisahkan dengan perusahaan atau departemen. Dukungan dari tiap manajemen yang berupa pengarahan, dukungan sumber daya seperti, memberikan peralatan yang memadai sebagai sarana untuk memudahkan pencapaian tujuan yang ingin dicapai dalam pendampingan, bimbingan, pelatihan serta pengembangan akan lebih baik mempermudah penilaian kinerja yang obyektif. Untuk dapat penilaian kinerja harus benar-benar diukur secara obyektif yaitu dengan cara yang sesungguhnya atau mengevaluasi perilaku yang mencerminkan keberhasilan peleksanaan pekerjaan. Penilaian kinerja yang obyektif akan memberikan feedback yang tepat terhadap perubahan perilaku ke arah peningkatan produktivitas kinerja yangdiharapkan (Hidayanti, dkk, 2008).

Permasalahan mengenai kinerja karyawan merupakan permasalahan yang akan selalu dihadapi oleh pihak manajemen sebuah organisasi, karena itu manajemen perlu mengetahui faktor-faktor yang dapat mempengaruhi kinerja karyawan. Faktorfaktor yang dapat mengetahui kinerja karyawan tersebut akan manajemen perusahaan atau departemen dapat mengambil berbagai kebijakan yang diperlukan, sehingga dapat meningkatkan kinerja karyawan agar sesuai harapan (Habibah, 2012).

Dalam Penelitian Hidayanti, (2008) yang berjudul Kecerdasan Emosi, Stres Kerja dan Kinerja Karyawan mempunyai tiga variabel. Variabel independen terdiri dari kecerdasan emosional dan stres kerja kemudian variabel dependennya adalah kinerja karyawan. Penelitian ini mengemukakan bahwa :

(a) Terdapat hubungan yang sangat signifikan antara kecerdasan emosional dan stres kerja dengan kinerja karyawan.

(b) Terdapat hubungan positif yang sangat signifikan antara kecerdasan emosi dengan kinerja karyawan.

(c) Terdapat hubungan negatif yang sangat signifikan antara stres kerja dengan kinerja karyawan.

Kecerdasan emosional dan stres kerja saling berkaitan dikarenakan ketika pegawai harus mampu menjaga emosinya tetap positif dan menggunakan emosinya sebagai motivasi dirinya sendiri untuk melaksanakan tugasnya dengan baik . diduga stres kerja yang ada pada karyawan di PT Laju perdana indah diakibatkan adanya tuntutan dan tekanan seperti pekerjaan yang harus diselesaikan terburu-buru (deadline) sehingga akan berdampak pada hasil kerja yang tidak mencapai target yang diberikan oleh perusahaan. Pada penelitian ini memiliki tujuan untuk menganalisis pengaruh kecerdasan emosional dengan stres karyawan, dengan kinerja karyawan PT Laju Perdana Indah. Penelitian akan dilakukan pada sebuah perusahaan perkebunan tebu PT Laju Perdana Indah yang memiliki lahan seluas 22.000 hektar lebih di Kecamatan Cempaka , Kabupaten Ogan Komering Ulu (OKU) Timur, Sumatra Selatan.

\section{Kecerdasan Emosional}


Menurut Salovey dan Mayer dalam Ivanc dalam saptoto. (2010: $\quad 3)$ mendefinsikan kecerdasan emosional digunakan untuk menggambarkan sejumlah keterampilan yang berhubungan dengan keakuratan penilaian tentang emosi diri sendiri dan orang lain, serta kemampuan mengelola perasaan untuk memotivasi,merencanakan, dan meraih tujuaj kehidupan.

Menurut Goleman dalam Nurita (2012 : 14) kecerdasan emosional adalah kecakapan emosional yang meliputi kemampuan untuk menegendaliakan diri sendiri, dan memiliki daya tahan ketikan menghadapi rintangan, mampun mengendalikan impuls dan tidak cepat merasa puas,mampu mengatur suasana hati dan mampu mengelola kecemasan agar tidak mengganggu kemampuan berpikir,mampu berempati serta berharap Kecerdasan emosional memiliki lima dimensi yang meliputi: kesadaran diri, manajemen diri, motivasi diri, empati, dan ketrampilan sosial (Goleman, dalam Luthans, 2013) dengan penjelasan sebagai berikut :

1) Kesadaran Diri

Kesadaran diri merupakan dimensi yang berhubungan dengan kemampuan untuk mengamati diri sendiri dan mengenali perasaan sejalan dengan perasaan yang terjadi. Pemahaman diri, pengetahuan tentang perasaan sebenarnya pada suatu keadaan.

2) Manajemen diri

Manajemen diri atau pengaturan emosi, yaitu kemampuan untuk mengendalikan perasaan agar sesuai dan merealisasikan apa yang terdapat dibalik perasaan tersebut, menemukan cara-cara untuk mengendalikan kekuatan dan kecemasan, kemarahan dan kesedihan. Kemampuan menangani emosi untuk memudahkan, bukan untuk menghalangi tugas atau pekerjaan, tidak menginginkan emosi negatif, dan kembali ke jalur konstruktif untuk penyelesaian masalah.

3) Motivasi diri

Motivasi diri adalah kemampuan untuk tetap pada tujuan yang diinginkan, mengatasi dampak emosi negatif dan menunda gratifikasi untuk memperoleh hasil yang diinginkan.
4) Empati

Empati yaitu sensitivitas yang tinggi terhadap perasaan dan perhatian orang lain, dan mengadaptasi perspektif mereka, mengapresiasikan berbagai perbedaan mengenai cara orang merasakan sesuatu. Dapat merasakan apa yang dirasakan dan diinginkan oleh orang lain.

5) Keterampilan sosial

Keterampilan sosial merupakan kemampuan mengendalikan emosi dalam diri orang lain, ketrampilan dan kompetensi sosial. Kemampuan membaca situasi sosial, lancar dan baik dalan komunikasi dengan orang lain dan membentuk jaringan, dapat mengendalikan emosi dan tindakan orang lain.

\section{Stres Kerja}

Stres ditempat kerja adalah sebuah masalah kritis yang makin bertambah bagi para pekerja dan masyarakat. stres di tempat kerja merupakan perhatian yang tumbuh pada keadaan ekonomi sekarang, di mana para karyawan menemui kondisi-kondisi kelebihan kerja, ketidaknyamanan kerja, tingkat kepuasan kerja yang rendah, ketiadaan ekonomi. Stres kerja telah tebukti mengakibatkan pengaruh yang merusak kesehatan dan kesejahteraan karyawan, seperti halnya berpengaruh negatif terhadap produktifitas dan keuntungan di tempat kerja. Stres biasanya didefinisikan dengan kondisikondisi internal dan eksternal yang menciptakan situasi-situasi yang penuh tertekan, dan gejala-gejalanya dialami oleh setiap orang yang tertekan (ivanko, 2012:88). Tingkat stres seseorang bergantung pada kemampuan-kemampuan yang dirasakan pada diri seeorang dan kepercayaan diri. Stres juga berkorelasi dengan ketakutan dan kegagalan seseorang.

Menurut Hasibuan (2014 : 204) stres kerja adalah kondisi ketegangan yang mempengaruhi emosi, proses berfikir dan kondisi seseorang. Stres biasanya dianggap sebagai sesuatu yang buruk, stres dianggap terjadi karena disebabkan oleh faktor negatif. Sedangkan Menurut Morgan dan King dalam Waluyo (2009) stres kerja adalah suatu keadaan yang bersifat internal, yang bisa 
disebabkan oleh tuntutan fisik (badan) atau lingkungan, dan situasi sosial yang berpotensi merusak dan tidak terkontrol. Sedangkan menurut Cooper dan Hager (1994) dalam Waluyo (2009) stres kerja didefinisikan sebagai tanggapan atau proses internal atau eksternal yang mencapai tingkat ketegangan fisik dan psikologis sampai pada batas atau melebihi batas kemampuan subyek. Stres didefinisikan sebagai reaksireaksi individu terhadap faktor-faktor baru atau yang mengancam dalam lingkungan kerja seseorang. Lingkungan kerja sering kali berisi situasi-situasi baru dan situasi-situasi tertekan yang bersifat individu, dan dapat dihasilkan dalam perubahan-perubahan emosional, perceptual, perilaku, dan fisiologis.

\section{B. METODE PENELITIAN}

Penelitian ini di laksanakan pada perusahaanPengaruh Kecerdasan Emosional Dan Stres Kerja terhadap Kinerja Karyawan pada PT Laju Perdana Indah di Oku Timur, peneltian ini adalah penelitian dengan menggunakan deskriptif kuantitatif dengan menggunakan data perimer dan data skunder dalam penelitian ini juga menggunakan wawancara dan kuesioner meliputi pertanyaan-pertanyaan yang berkenaan dengan keadaan perusahaan yang berkaitan dengan kecerdasan emosional dan stres kerja. Serta dilakukan observasi, yaitu melakukan pengamatan secara langsung terhadap objek yang akan diteliti pada perusahaan yang terkait dengan mencatat data yang diharapkan menjadi masukan dan informasi yang berhubungan dengan masalah pengaruh kecerdasan emosional dan stres kerja terhadap kinerja karyawan, populasi dalam penelitian ini sebanyak 150 Karyawan dngan menggunakan Menurut Sugiyono (2009:81) sampel adalah bagian dari jumlah dan karakteristik yang dimiliki oleh populasi tersebut. Sampel yang diambil dari populasi harus betul-betul representatif (mewakili). Teknik pengambilan sampel dalam penelitian ini dengan sebanyak 150 karyawan PT. Laju Perdana Indah. Sampel yang diambil dalam masing-masing bagian dan pengambilan sampel dengan menggunakan rumus Slovin, sebagai berikut :

$$
\mathrm{n}=\frac{\mathrm{N}}{1+\mathrm{Ne}^{2}}
$$

Keterangan :

$\mathrm{n}=$ Jumlah Sampel

$\mathrm{N}=$ Jumlah Populasi

$\mathrm{e}=$ Presentasi $(10 \%)$ toleransi ketidaktelitian karena kesalahan yang ditolerir )

0-21= bilangan konstan

Berdasarkan rumus slovin diatas, maka jumlah sampel yang diambil adalah sebagai berikut :

$$
\begin{aligned}
& \mathrm{n}=\frac{\mathrm{N}}{1+\mathrm{Ne}^{2}} \\
& \mathrm{n}=\frac{150}{1+(150 \times 0,1)^{2}} \\
& \mathrm{n}=\frac{151}{2,5} \\
& \mathrm{n}=\quad 60,4 \\
& \mathrm{n}=
\end{aligned}
$$

Jadi, jumlah sampel yang akan digunakan dalam penelitian adalah sebesar 60 orang karyawan yang mewakili populasi yang dipilih secara acak.

\section{Rancangan Penelitian}

Untuk mempermudah proses penelitian data, maka perlu dilakukan rancangan penelitian. Rancangan penelitian yang digunakan penulis dalam proposal ini menggunakan metode deskriptif kuantitatif. Dalam penelitian ini penulis menggunakan 3 variabel yaitu : 2 variabel bebas (independen) dan variabel terikat (dependen).

Variabel X1 : Kecerdasan emosional

Variabel X2 :Stres Kerja

Variabel Y : Kinerja Karyawan

Rancangan penelitian dalam penelitian ini meliputi :

1. Tujuan studi

Tujuan studi dalam penelitian ini adalah deskriptif yatiu studi yang dilakukan untuk mengetahui dan menggambarkan 
karakteristik dari variabel-variabel dalam pemecahan masalah-masalah yang berkaitan dengan hasil penelitian.

2.Hubungan antar variabel

Hubungan antar variabel dalam penelitian ini bersifat kausal, yang berarti adanya hubungan-hubungan sebab akibat antara variabel-variabel independen terhadap variabel dependen, yaitu pengaruh variabel kecerdasan emosional (X1) dan stres kerja (X2) terhadap kinerja karyawan.

\section{Unit analisis}

Unit analisis dalam penelitian ini adalah individu-individu karyawan pada PT Laju Perdana Indah di Oku Timur dimana data yang diperoleh subyektif berdasarkan jawaban - jawaban individu-individu karyawan tersebut sebagai responden.

\section{Instrumen Penelitian}

Instrumen penelitian yang penulis lakukan dengan menggunakan kuesioner. Kuesioner adalah sejumlah pertanyaan tertulis yang digunakan untuk memperoleh informasi dari responden dalam kaitannya tentangkecerdasan emosional dan stres kerja terhadap kinerja karyawan pada PT Laju Perdana Indah.

Haryono (2016:43), Instrumen penelitian harus memenuhi persyaratan keabsahan (validity) dan keterandalan (reability). Prinsip keabsahan dapat dipenuhi bila instrument tersebut mengukur sesuatu yang harus diukur prinsip keandalan dapat dipenuhi bila instrumen tersebut dapat menghasilkan data yang stabil dan konsisten secara tidak berfluktuasi dan terkontaminasi (bias) oleh waktu dan tempat. Dalam pengolahan data yang berbentuk kuesioner diperlukan uji reliabilitas dan uji validitas dengan alat ukur skala Likert.

\section{Uji Kualitas Data}

1. Uji Validitas yaitu derajat ketepatan atau kelayakan instrumen yang digunakan untuk mengukur apa yang akan diukur serta sejauh mana instrumen tersebut menjalankan fungsi pengukurannya. Untuk melakukan Uji Validitas ini menggunakan program SPSS (Statistical Product and Service Solutions).

2. Uji Realibilitas yaitu konsistensi dari serangkaian pengukuran atau serangkaian alat ukur yang sering kali diandalkan untuk mengukur secra konsisten setelah dilakukan berulang - ulang kali tes terhadap subjek dan dalam kondisi yang sama.

\section{Teknik analisis data}

Seluruh data yang dikumpulkan yang berasal dari seluruh pertanyaan kemudian ditabulasikan sesuain dengan analisis yang dibutuhkan adapun analisis yang dibutuhkan dalam penelitian ini berdasarkan tujuan dan hipotesis, untuk menguji yaitu untuk mengetahui pengaruh kecerdasan emosional dan stres kerja terhadap kinerja karyawan, digunakan :

\section{Analisis statistik deskriptif}

Analisis deskriptif digunakan untuk mendapatkan suatu gambaran mengenai responden dalam penelitian ini. Dalam penulisan ini penulis akan membahas mengenai bentuk jawaban responden terhadap seluruh konsep yang diukur. Dari jawaban responden selanjutnya akan diperoleh satu kecenderungan atas jawaban responden tersebut. Skala yang digunakan dalam penelitian ini adalah skala likert. Menurut (ghozali, 2009) skala likert adalah skala yang berisi 5 tingkat prefensi jawaban dengan pilihan sebagai berikut :

$$
\begin{aligned}
& 1=\text { Sangat Setuju } \\
& 2=\text { Setuju } \\
& 3=\text { Ragu-Ragu } \\
& 4=\text { Tidak Setuju } \\
& 5=\text { Sangat Tidak Setuju }
\end{aligned}
$$

\section{Teknik Analisis statistik Inferensial}

1. Analisis regresi linear berganda

Analisis regresi linear berganda digunakan untuk mengetahui pengaruh kecerdasan emosional dan stres kerja terhadap kinerja karyawan pada PT Laju Perdana Indah, dengan rumus sebagai berikut

Keterangan :

$$
\mathrm{Y}=\alpha+\mathrm{b} 1 \mathrm{X} 1+\mathrm{b} 2 \mathrm{X} 2+\mathrm{e}
$$

$\mathrm{Y}=$ Variabel Kinerja

$\mathrm{X} 1=$ Variabel Kecerdasan Emosional

$\mathrm{X} 2=$ Variabel Stres Kerja

$\alpha=$ Konstanta

b1 b2 = Koefesien regresi ( Kecerdasan emosional dan stres kerja) 
e $\quad=$ Residu

2. Analisis koefisien

Menurut sugiyono (2010 : 248) analisis koefisien adalah hubungan linear antara dua variabel atau lebih dari pengamatan untuk menguji hipotesi asosiatif. Analisis korelasi hubungan antara variabel bebas dan variabel terikat dapat menggunakan teknik analisi sederhana dan teknik analisis berganda.

\section{Uji Hipotesis Statistik}

\section{Uji Simultan ( Uji F )}

Menurut riduwan ( 2004 :165 ) uji-f adalah "pengujian yang dilakukan untuk mengetahui kemampuan data sampel yang memiliki dua aspek atau lebih dan dianggap dapat mewakili populasi."

Dengan langkah - langkah sebagai berikut :

\section{Hipotesis I :}

Formulasi $\mathrm{H}_{0}$ dan $\mathrm{H}_{1}$

$\mathrm{H}_{0}: \mathrm{b}_{1}=\mathrm{b}_{2}=0$ (tidak ada pengaruh kecerdasan emosional dan stres kerja terhadap kinerja karyawan pada PT Laju Perdana Indah di Oku Timur).

$\mathrm{H}_{1}: \mathrm{b}_{1} \neq \mathrm{b}_{2} \neq 0$ ( ada pengaruh pengaruh kecerdasan emosional dan stres kerja terhadap kinerja karyawan pada PT Laju Perdana Indah di Oku Timur).

Menentukan level og significant (a) = 0,05

a. Kriteria pengujian

Ho diterima jika F sig $\geq 0,05$

Ho ditolak jika F sig $<0,05$

b. Kesimpulan menerima atau menolak H0

\section{Uji secara Parsial, digunakan Uji t} berikut :

Dengan langkah - langkah sebagai

\section{Hipotesis 2 :}

Formula $\mathrm{HO}$ dan $\mathrm{H} 1$

Ho $: b_{1}=0$ ( tidak ada pengaruh pengaruh kecerdasan emosional dan stres kerja terhadap kinerja karyawan pada PT Laju Perdana Indah di Oku Timur).

$\mathrm{H}_{1}: \mathrm{b}_{1} \neq 0$ ( ada pengaruh pengaruh kecerdasan emosional dan stres kerja terhadap kinerja karyawan pada PT Laju Perdana Indah di Oku Timur. ).

a. Menentukan level of significant (a) $=0,05$

b. Kriteria pengujian
Ho diterima jika $\mathrm{t}$ sig $\geq 0,05$

Ho ditolak jika tsig $<0,05$

c. Kesimpulan menerima atau menolak H0

\section{Hipotesis 3 :}

Formulasi $\mathrm{H} 0$ dan $\mathrm{H} 1$

H0 : $b_{1}=0$ ( tidak pengaruh pengaruh kecerdasan emosional dan stres kerja terhadap kinerja karyawan pada PT Laju Perdana Indah di Oku Timur ).

H1 $: b_{1} \neq 0$ ( ada pengaruh pengaruh kecerdasan emosional dan stres kerja terhadap kinerja karyawan pada PT Laju Perdana Indah di Oku Timur ).

Menentukan level og significant (a) $=0,05$

a. Kriteria pengujian

Ho diterima $\mathrm{t}$ sig $\geq 0,05$

Ho ditolak $\mathrm{t}$ sig $<0,0$

\section{HASIL DAN PEMBAHASAN Hasil Uji Validitas}

Uji validitas dilakukan dengan responden sebanyak 60 orang sebagai uji coba kuesioner.Syarat suatu instrument dinyatakan valid adalah bila koefisien kolerasi $\geq 0,300$ atau bisa juga membandingkan dengan $r$ tabel.Jika $r$ hitung $>\mathrm{r}$ tabel maka instrument tersebut valid (Sugiyono, 2012).Berdasarkan analisis yang telah dilakukan.Adapun hasil uji validitas selengkapnya dapat dilihat pada tabel dibawah ini.

Tabel 1. Hasil Uji Validitas Variabel

KecerdasanEmosional $\left(\mathrm{X}_{1}\right)$

\begin{tabular}{|c|c|c|c|c|}
\hline $\begin{array}{c}\text { No } \\
\text { Item }\end{array}$ & $\begin{array}{c}\mathbf{r} \\
\text { Hitung }\end{array}$ & $\begin{array}{c}\mathbf{r} \\
\text { Tabel }\end{array}$ & Kriteria & Keterangan \\
\hline 1 & $0.921^{* *}$ & 0,300 & $\mathrm{r}$ hitung $\geq \mathrm{r}$ table & Valid \\
\hline 2 & $0.932^{* *}$ & 0,300 & $\mathrm{r}$ hitung $\geq \mathrm{r}$ table & Valid \\
\hline 3 & $0.828^{* *}$ & 0,300 & $\mathrm{r}$ hitung $\geq \mathrm{r}$ table & Valid \\
\hline 4 & $0.915^{* *}$ & 0,300 & $\mathrm{r}$ hitung $\geq \mathrm{r}$ table & Valid \\
\hline 5 & $0.893^{* *}$ & 0,300 & $\mathrm{r}$ hitung $\geq \mathrm{r}$ table & Valid \\
\hline 6 & $0.839^{* *}$ & 0,300 & $\mathrm{r}$ hitung $\geq \mathrm{r}$ table & Valid \\
\hline
\end{tabular}

Sumber : Hasil Pengolahan Data Menggunakan SPSS. 20.00

Berdasarkan tabel diatas diperoleh nilai $r_{\text {hitung }} u n t u k$ setiap butir pernyataan pada variabel KecerdasanEmosional $\left(\mathrm{X}_{1}\right)>$ $\mathrm{r}_{\text {tabel }} 0,300$ dengan demikian maka dapat dijelaskan bahwa semua butir pernyataan variabel KecerdasanEmosional dinyatakan valid. 
Tabel 2. Hasil Uji Validitas Variabel Stres Kerja $\left(\mathbf{X}_{2}\right)$

\begin{tabular}{|c|c|c|c|c|}
\hline $\begin{array}{c}\text { No } \\
\text { Item }\end{array}$ & r Hitung & $\begin{array}{c}\mathbf{r} \\
\text { Tabel }\end{array}$ & Kriteria & Keterangan \\
\hline 1 & $0.712^{* *}$ & 0,300 & r hitung $\geq$ r table & Valid \\
\hline 2 & $0.815^{* *}$ & 0,300 & r hitung $\geq$ r table & Valid \\
\hline 3 & $0.710^{* *}$ & 0,300 & r hitung $\geq$ r table & Valid \\
\hline 4 & $0.853^{* *}$ & 0,300 & r hitung $\geq$ r table & Valid \\
\hline 5 & $0.819^{* *}$ & 0,300 & r hitung $\geq$ r table & Valid \\
\hline 6 & $0.728^{* *}$ & 0,300 & r hitung $\geq$ r table & Valid \\
\hline
\end{tabular}

Sumber : Hasil Pengolahan Data Menggunakan SPSS. 20.00

Berdasarkan tabel diatas diperoleh nilai $\mathrm{r}_{\text {hitung }}$ untuk setiap butir pernyataan pada variabel Stres Kerja $\left(\mathrm{X}_{2}\right)>\mathrm{r}_{\text {tabel }}$ 0,300 dengan demikian maka dapat dijelaskan bahwa semua butir pernyataan variabel Stres Kerja dinyatakan valid.

Tabel 4. Hasil Uji Validitas Variabel Kinerja Karyawan (Y)

\begin{tabular}{|c|c|c|c|c|}
\hline $\begin{array}{c}\text { No } \\
\text { Item }\end{array}$ & r Hitung & $\begin{array}{c}\mathbf{r} \\
\text { Tabel }\end{array}$ & Kriteria & Keterangan \\
\hline 1 & $0.783^{* *}$ & 0,300 & $\mathrm{r}$ hitung $\geq \mathrm{r}$ table & Valid \\
\hline 2 & $0.869^{* *}$ & 0,300 & $\mathrm{r}$ hitung $\geq \mathrm{r}$ table & Valid \\
\hline 3 & $0.817 * *$ & 0,300 & $\mathrm{r}$ hitung $\geq \mathrm{r}$ table & Valid \\
\hline 4 & $0.820^{* *}$ & 0,300 & $\mathrm{r}$ hitung $\geq \mathrm{r}$ table & Valid \\
\hline 5 & $0.806^{* *}$ & 0,300 & $\mathrm{r}$ hitung $\geq \mathrm{r}$ table & Valid \\
\hline 6 & $0.764^{* *}$ & 0,300 & $\mathrm{r}$ hitung $\geq \mathrm{r}$ table & Valid \\
\hline
\end{tabular}

Sumber : Hasil Pengolahan Data Menggunakan SPSS. 20.00

Berdasarkan tabel diatas diperoleh nilai $r_{\text {hitung }}$ untuk setiap butir pernyataan pada variabel Kinerja Karyawan $>\quad r_{\text {tabel }} 0,300$ dengan demikian maka dapat dijelaskan bahwa semua butir pernyataan variabel Kinerja Karyawan dinyatakan valid.

\section{Hasil Uji Reliabilitas}

Uji reliabilitas digunakan untuk mengukur konsistensi variabel penelitian. Untuk melihat reliabilitas instrument akan dihitung Alpha Cronbach masing-masing instrument. Menurut Arikunto variabel dikatakan reliable jika memiliki nilai Alpha Cronbach $\geq 0,600$. Hasil uji reliabilitas dalam penelitian ini dapat dilihat pada tabel 4.7 sebagai berikut :
Tabel 3. Hasil Uji Reliabilitas Variabel Penelitian

\begin{tabular}{|c|c|c|c|}
\hline Variabel & $\begin{array}{l}\text { Cronbach's } \\
\text { Alfa }\end{array}$ & Kriteria & Keterangan \\
\hline $\begin{array}{l}\text { Kecerdasan } \\
\text { Emosional }\end{array}$ & 0,945 & $>0,600$ & Reliabel \\
\hline Stres kerja & 0,867 & $>0,600$ & Reliabel \\
\hline $\begin{array}{l}\text { Kinerja } \\
\text { Karyawan }\end{array}$ & 0,893 & $>0,600$ & Reliabel \\
\hline
\end{tabular}

Berdasarkan tabel 3 hasil pengujian reliabilitas di atas dapat diketahui bahwa semua variabel baik dari Kecerdasan Emosional, Stres kerja, dan Kinerja Karyawan memiliki nilai Alpha Cronbach lebih besar dari 0,600, maka dapat disimpulkan bahwa semua variabel dalam penelitian ini dinyatakan reliable/diterima.

Tabel 4. Hasil Uji Regresi Linier Berganda

\begin{tabular}{|c|c|c|c|c|c|}
\hline \multirow[b]{2}{*}{ Model } & \multicolumn{2}{|c|}{$\begin{array}{l}\text { Unstandardized } \\
\text { Coefficients }\end{array}$} & \multirow{2}{*}{$\begin{array}{c}\begin{array}{c}\text { Standardized } \\
\text { Coefficients }\end{array} \\
\text { Beta }\end{array}$} & \multirow[b]{2}{*}{$t$} & \multirow[b]{2}{*}{ Sig. } \\
\hline & $B$ & Std. Error & & & \\
\hline $1 \quad$ (Constant) & -2.965 & 1.591 & & -1.864 & .067 \\
\hline $\mathrm{x} 1$ & .460 & .094 & .469 & 4.909 & .000 \\
\hline$x 2$ & .545 & .108 & .480 & 5.025 & .000 \\
\hline
\end{tabular}

Berdasarkan pada hasil analisis yang telah dilakukan, maka persamaan regresi yang terbentuk adalah sebagai berikut: $Y=-2.965+0,460 X_{1}+0,545 X_{2}$ Dari persamaan diatas dapat dijelaskan sebagai berikut :

1) Konstanta $(\alpha)$ sebesar $\quad-2.965$ menyatakan bahwa jika variabel independen dikatakan konstan atau $=0$, maka Kinerja Kerja Karyawan hanya sebesar -2.965

2) Koefisien regresi Emosional( $\left.b_{1}\right)$ sebesar 0,460 hasil tersebut dapat diartikan bahwa setiap peningkatan KecerdasanEmosional sebesar $1 \%$ maka akan mengakibatkan peningkatan Kinerja karyawan sebesar 0,460

3) Koefisien regresi Stres kerja $\left(b_{2}\right)$ sebesar 0,545 hasil tersebut dapat diartikan bahwa setiap peningkatan Stres kerja 1\% 
maka akan mengakibatkan Kinerja karyawan sebesar 0,545

\section{Analisis Korelasi dan determinasi Uji Koefisien Korelasi Sederhana (r)}

Analisis koefisien dapat digunakan untuk membandingkan hasil pengukuran dua variabel yang berbeda agar dapat menentukan hasil hubungan antar variabel. Adapun hasil uji koefisien korelasi pada penelitian ini adalah sebagai berikut :

\section{Analisis Regresi Linier Berganda}

Hasil analisis regresi berganda dengan menggunakan SPSS 20.00 pada penelitian ini dapat dilihat pada tabel di bawah ini :

Tabel 5. Hasil Uji Koefisien Korelasi Model Summary

\begin{tabular}{l|r|r|r|r|}
\hline Model & $\mathrm{R}$ & $\begin{array}{c}\mathrm{R} \\
\text { Square }\end{array}$ & $\begin{array}{c}\text { Adjusted R } \\
\text { Square }\end{array}$ & $\begin{array}{r}\text { Std. Error of } \\
\text { the Estimate }\end{array}$ \\
\hline 1 & $.900^{\mathrm{a}}$ & .811 & .804 & 1.710 \\
\hline
\end{tabular}

Dari hasil output di atas diketahui bahwa nilai korelasi antara variabel Kecerdasan Emosional dan Stres kerja dengan variabel Kinerja kerja karyawan sebesar 0,900 angka tersebut menunjukkan bahwa terdapat korelasi yang kuat antara variabel KecerdasanEmosional dan Stres kerja dengan variabel Kinerja kerja karyawanApabila dilihat dari nilai signifikan dari seluruh variabel yaitu sebesar $0.000<$ 0,05 , hal ini menunjukan bahwa terdapat korelasi antara seluruh variabel.

Uji Hipotesis

Pengujian hipotesis dilakukan untuk menguji hipotesis yang telah dibuat dan melihat seberapa besar pengaruh Emosional, Stres kerja terhadap Kinerja kerja karyawan.Pengujian hipotesis dilakukan dengan menguji secara bersama-sama terhadap Kinerja kerja karyawan (dalam uji f).dan pengaruh masing-masing terhadap Kinerja kerja karyawan (dalam uji t)

\section{Hasil Uji F}

\begin{tabular}{lll}
\multicolumn{3}{c}{ Uji F digunakan untuk menguji ada } \\
tidaknya & pengaruh variabel-variabel \\
independen & terhadap variabel dependen
\end{tabular} secara simultan (bersama-sama). Hasil uji $\mathrm{F}$ dapat dilihat pada tabel 6

Tabel 6. Hasil Uji F (Uji Secara simultan) ANOVA $^{b}$

\begin{tabular}{|l|r|r|r|r|r|}
\hline Model & \multicolumn{1}{|c|}{$\begin{array}{c}\text { Sum of } \\
\text { Squares }\end{array}$} & \multicolumn{1}{c|}{ Df } & \multicolumn{1}{c|}{$\begin{array}{c}\text { Mean } \\
\text { Square }\end{array}$} & F & Sig. \\
\hline 1 Regression & 714.187 & 2 & 357.094 & 122.129 & $.000^{\mathrm{a}}$ \\
& 166.663 & 57 & 2.924 & & \\
Residual & 880.850 & 59 & & & \\
Total & & & & \\
\hline
\end{tabular}

a. Predictors: (Constant), x2, x1

Berdasarkan uji ANOVA atau F test yang dapat dilihat pada tabel 4.10 Maka dapat diperoleh $F_{\text {hitung sebesar 122,129 }}$ dengan tingkat signifikansi 0,000 .Oleh karena nilai Signifikan. jauh lebih kecil daripada $(\alpha)$ 0,05 maka dapat dinyatakan bahwa variabel independen yang meliputi Kecerdasan Emosional $\left(\mathrm{X}_{1}\right)$, Stres kerja $\left(\mathrm{X}_{2}\right)$ secara simultan atau bersama-sama Mempengaruhi variabel Kinerja kerja karyawan (Y) secara signifikan.

Uji t

Hipotesis yang diuji adalah : Uji $\mathrm{t}$ yaitu suatu uji untuk mengetahui pengaruh variabel bebas (Kecerdasan Emosional dan Stres Kerja) secara parsial (masing-masing) menerangkan variabel terikat (Kinerja kerja karyawan)

Tabel 7. Hasil Uji t

\begin{tabular}{|c|c|c|c|c|c|}
\hline \multirow[b]{2}{*}{ Model } & \multicolumn{2}{|c|}{$\begin{array}{l}\text { Unstandardized } \\
\text { Coefficients }\end{array}$} & \multirow{2}{*}{ 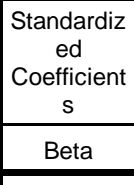 } & \multirow[b]{2}{*}{$\mathrm{t}$} & \multirow[b]{2}{*}{ Sig. } \\
\hline & B & Std. Error & & & \\
\hline $\begin{array}{ll}1 & \text { (Constan } \\
\text { t) }\end{array}$ & -2.965 & 1.591 & & -1.864 & .067 \\
\hline $\mathrm{x} 1$ & .460 & .094 & .469 & 4.909 & .000 \\
\hline$x 2$ & .545 & .108 & .480 & 5.025 & .000 \\
\hline
\end{tabular}

a. $\mathrm{H}_{0}: \mathrm{b}_{1}=\mathrm{b}_{2}=0$, artinya, Kecerdasan Emosional secara parsial tidak mempunyai pengaruh terhadap Kinerjakerja karyawan.

b. $\mathrm{H}_{1}: \mathrm{b}_{1} \neq \mathrm{b}_{2} \neq 0$, artinya Kcerdasan Emosiona dan Stres Kerja secara parsial mempunyai pengaruh terhadap Kinerja kerja karyawan 
c. Pengujian dilakukan dengan uji $\mathrm{t}$ adalah memperhatikan derajat signifikan $95 \%(a=0,05)$, apabila hasil pembuktian menunjukan : t sig $>\alpha$, maka $\mathrm{H}_{0}$ ditolak dan $\mathrm{H}_{\mathrm{a}}$ diterima t sig $<\alpha$, maka $\mathrm{H}_{0}$ diterima dan $\mathrm{H}_{\mathrm{a}}$ ditolak

Hasil analisis uji t adalah sebagai berikut :

1).Nilai $t_{\text {hitung }}$ pada variabel Kecerdasan Emosional (X1) adalah sebesar 4.909 dengan tingkat signifikan sebesar 0,000 Karena signifikansinya $0,000<$ (a) 0,05 maka $\mathrm{H}_{0}$ diterima dan $\mathrm{H}_{\mathrm{a}}$ ditolak.

Kesimpulan : Kecerdasan Emosional berpengaruh signifikan terhadap Kinerja kerja karyawan.

2).Nilai $t_{\text {hitung }}$ pada variable Stres Kerja (X2) adalah sebesar 5.025 dengan tingkat signifikansi sebesar 0,000 Karena signifikansinya $0,000>(\alpha) \quad 0,05$ maka $\mathrm{H}_{0}$ diterima dan $\mathrm{H}_{\mathrm{a}}$ ditolak

Kesimpulan :Stres kerja berpengaruh signifikan terhadap Kinerja kerja karyawan

\section{SIMPULAN DAN SARAN}

Berdasarkan hasil penelitian dan hasil analisis data dapat ditarik beberapa kesimpulan sebagai berikut :

1. Secara simultan atau bersama - sama ada pengaruh Kecerdasan Emosiona $1\left(\mathrm{X}_{1}\right)$ dan Stres $\operatorname{kerja}\left(\mathrm{X}_{2}\right)$ terhadap Kinerja Kerja Karyawan(Y)hal ini dapat dilihat dari hasil ujiF (ANOVA) Apabila dilihat dari nilai Signifikannya $0,000 \leq(\alpha) 0,05$.

2. Dari hasil analisis Uji Koefisien Korelasi sederhana, nilai korelasi antara variabel Kecerdasan Emosional dengan variabel Kinerja kerja karyawan sebesar 0,811 angka tersebut menunjukkan bahwa terdapat korelasi yang kuat antara variabel Kecerdasan Emosional dengan variabel Kinerja kerja karyawan. Begitu juga nilai korelasi antara variabel Stres kerja dengan variabel Kinerja kerja karyawan adalah sebesar 0,811 angka tersebut juga menunjukkan bahwa terdapat korelasi yang kuat antara variabel Stres kerja dengan variabel Kinerja kerja karyawan.
Saran

Beberapa saran yang dapat peneliti rekomendasikan kepada pihak manajemen PT. Laju Perdana Indah di Oku Timur antara lain :

1. Perlu adanya perhatian dalam menjaga Kecerdasan Emosional dan Stres kerja didalam bekerja agar pekerjaan lebih bagus dan rapi.

2. Bagi peneliti selanjutnya, hasil penelitian ini dapat dijadikan sebagai sumber untuk melakukan penelitian lebih lanjut mengenai Kinerja kerja karyawan dengan menggali variabel lain yang tidak peneliti ambil dalam penelitian ini, misalnya Iklim kerja, Kompetensi atau Diklat.

\section{E. DAFTAR RUJUKAN}

Aditya, Reza Regina. 2013. Pengaruh Gaya Kepemimpinan, Motivasi, dan Disiplin Kerja terhadap Kinerja Karyawan PT. Sinar Santosa PerkasaBanjarnegara. Universitas Diponegoro, Semarang.

Bambang, Irawan. 2010. Manajemen Resiko. Jakarta : Universitas Airlangga

Edy Sutrisno. 2011. Manajemen Sumber Daya Manusia. Jakarta: Kencana.

Hasibuan, Melayu. 2012. Manajemen Sumber Daya Manusia. Jakarta: PT. Bumi Aksara.

Haryono. H, Amirul \& Hadi. 2012. Metodologi Penelitian Pendidikan, Bandung: Pustaka Setia.

Jorfi, Hasan. 2010. Impact of Emotional Intelligence on Performance ofEmployees. Postmodern Openings, Year 1, Vol 4, December, pp: 63-74

Maryani. 2016.Pengaruh Kecerdasan Emosional dan Stres kerja Terhadap Kinerja Pegawai Badan Pengelolaan Lingkungan Hidup dan Kebersihan di Kabupaten Tanggamus .

Nawawi, Hadari. 2011. Manajemen Sumber Daya Manusia untuk Bisnis yangKompetitif. Yogyakarta: Gadjah Mada University Press.Noviansyah dan Zunaidah. 2011. Pengaruh Stres Kerja Dan Motivasi Kerja Terhadap Kinerja Karyawan PT. Perkebunan Minanga Ogan Baturaja

Payama J. Simanjuntak. 2014. Manajemen dan Evaluasi Kinerja. Lembaga Penerbit FEUI 
Rivai Veitzhal, \& Mulyadi. 2009. Manajemen Sumber Daya Manusia. Cetakan kesembilan.Robbins, S. P., \& Judge, T. A. 2008. Perilaku Organisasi - Organizational Behavior (Vol. Edisi 12). (R. C. Diana Angelica, Penerj.) Jakarta: Salemba Empat.

Sugiyono. 2016. Metode Penelitian Bisnis. Alfabeta, Bandung.

Sirait Justine. 2006. Memahami Aspek-Aspek Pengelolaan Sumber Daya Manusia Dalam Organisasi. Penerbit PT. Gramedia Widiasarana Indonesia, Jakarta.

Salinding, Rony. 2011. Analisis Pengaruh Pelatihan terhadap Produktivitas Kerja Karyawan Pada PT. Erajaya Swasembada Cabang Makasar. Universitas Hassanudin Makasar. 